\title{
Methanolic Leaf Extract of Diospyros chloroxylon Modulates Hepatic Redox Profile and Cell Proliferation in Dimethylamine-treated Rats
}

\author{
G. E. Adeleke ${ }^{1}$, O. T. Adedosu ${ }^{1 *}$, O. K. Afolabi ${ }^{1}$, O. O. Arinde ${ }^{1}$ \\ and T. M. Oyedokun ${ }^{1}$ \\ ${ }^{1}$ Department of Biochemistry, Ladoke Akintola University of Technology, P.M.B. 4000, Ogbomoso, \\ Oyo State, Nigeria. \\ Authors' contributions \\ This work was carried out in collaboration between all authors. Author GEA designed the study, \\ performed the statistical analysis, wrote the protocol and wrote the first draft of the manuscript. \\ Authors OTA and OKA managed the analyses of the study. Authors OOA and TMO managed the \\ literature searches. All authors read and approved the final manuscript.
}

Article Information

DOI: $10.9734 / B J M M R / 2017 / 33242$

Editor(s):

(1) Georgios Tsoulfas, Assistant Professor of Surgery, Aristoteleion University of Thessaloniki, Thessaloniki, Greece.

Reviewers:

(1) Waseem Rizvi, Aligarh Muslim University Aligarh, India.

(2) Weiting Wang, Tianjin Institute of Pharmaceutical Research, Tianjin, China. Complete Peer review History: http://www.sciencedomain.org/review-history/19351

Original Research Article

Received $5^{\text {th }}$ April 2017

Accepted $3^{\text {rd }}$ May 2017

Published $5^{\text {th }}$ June 2017

\begin{abstract}
Dimethylamine (DMA) is a toxicant commonly present in foods, air and water. Diospyros species is a group of plants being reported to contain several bioactive agents. The study was aimed at investigating the biological activities of Diospyros chloroxylon leaf extract (DCLE) on DMA-induced toxicity in liver of Wistar rats. The DMA significantly $(p<0.05)$ reduced serum Superoxide dismutase (SOD) and catalase activities by $43.9 \%$ and $60.6 \%$, while malondialdehyde (MDA) was found to be significantly ( $p<0.05$ ) elevated by $150 \%$ compared with controls. Hepatic SOD and catalase activities, and reduced glutathione (GSH) level were significantly $(p<0.05)$ reduced by $49.9 \%, 32 \%$ and $26.3 \%$, respectively, while MDA level was increased by $94.5 \%$ in DMA group against controls. The DCLE significantly $(p<0.05)$ increased SOD and catalase activities, and lowered MDA level in serum and liver against DMA treatment. DNA fragmentation was observed to be significantly elevated by $42.5 \%$ in DMA-treated rats compared with controls. Pretreatment with
\end{abstract}

*Corresponding author: E-mail: laniyidosu@yahoo.com, otadedosu@lautech.edu.ng; 
DCLE significantly $(\mathrm{p}<0.05)$ lowered DNA fragmentation in the [DCLE + DMA] group. Histological data reveal that DMA caused periportal cell infiltration in hepatocytes, whereas the control, DCLE and [DCLE + DMA] groups showed no visible lesion. Immunohistochemical (IHC) staining of CD34 showed a strong expression in DMA group, while DCLE + DMA] showed a moderate expression. This study thus suggests that methanolic leaf extract of Diospyros chloroxylon ameliorates oxidative stress, DNA damage and cell proliferation in liver of rats treated with Dimethylamine.

Keywords: Dimethylamine; Diospyros chloroxylon; redox profile; DNA damage; cell proliferation.

\section{INTRODUCTION}

Dimethylamine (DMA) is a secondary amine, occurring as an environmental toxicant and a contaminant of foods such as cabbage, celery, corn, and coffee. In vivo metabolism of amines have been exemplified by arylamines (aromatic amines), which are metabolized via hepatic CYP 450-dependent $N$-hydroxylation [1], followed by phase II esterification of the $\mathrm{N}$-hydroxylamine to reactive ester derivatives that covalently bind DNA [2]. AlAs have been demonstrated to exhibit genotoxicity in cultured mammalian cells, by showing mutagenesis, chromosomal aberrations and DNA strand breaks [3]. These amines have been observed as potential bacterial mutagens, as well as, animal and human carcinogens [4]. However, DMA has been a potential precursor of $\mathrm{N}$-nitrosodimethylamine (NDMA), both chemically and biologically, when reacted with nitrate or nitrite. This nitrosamine is a potent environmental toxicant present in foods and drinking water [57]. In vivo formation of NDMA has been demonstrated in mice with oral administration of DMA and nitrite [8], and also through intubation with DMA followed by inhalation of nitrogen (IV) oxide $\left(\mathrm{NO}_{2}\right)$, as reported by lqbal [9]. Microbial synthesis of NDMA from DMA and sodium nitrite has been recently noticed by Adeleke et al. [10], using a culture of Acetobacter aceti isolated from fermented palm wine, a finding that supported the endogenous generation of this nitrosamine by human gut bacteria [11-12]. Mammalian metabolism of NDMA occurs via CYP 450dependent a-hydroxylation reaction to form methyldiazohydroxide, which is finally converted to methyldiazonium ion, an electrophile that can methylate DNA molecule [13-15]. Several studies have shown that $N$-Nitrosamines are mutagenic and can produce free radicals in cellular systems [16-17], leading to carcinogenesis [18]. In addition, NDMA has been reported to induce hepatic necrosis [19], genotoxicity, pathologic apoptosis and cell proliferation [20].
Diospyros species is a large genus of trees or shrubs, belonging to family Ebenaceae, which are widely distributed all over the world. The leaves of Diospyros chloroxylon have been used for curing several diseases such as boils, pains, swelling and skin diseases [21]. Some researchers have linked the medicinal values of Diospyros species to the presence of phytochemicals such as, usorlic, diospyrin, amytrin, [22-23]. Certain phytochemical studies of the leaves of $D$. chloroxylon indicated the presence of a broad spectrum of secondary metabolites, such as cardiac glycosides, alkaloids, flavonoids, tannins, amino acids, proteins and saponins [24]. A more recent phytochemical study by Thomas et al. [25], using acetone extract of $D$. chloroxylon leaves revealed the presence of terpenoids, alkaloids, tannins, phenols and saponins. A novel triterpene, betulinic acid, has been reported present in Diospyros species [26-27], and could also exhibit several biological properties [28-30]. Literature information on the effects of $D$. chloroxylon against dimethylamine toxicity was scarce. Therefore, this study was designed to investigate the biological activities of $D$. chloroxylon methanolic leaf extract in rats treated with dimethylamine.

\section{MATERIALS AND METHODS}

\subsection{Chemicals}

Dimethylamine hydrochloride (DMA-HCl) was purchased from Sigma Aldrich (St. Loius, MO, USA). All other chemicals and reagents used are of good analytical grade.

\subsection{Plant Material}

The leaves of Diospyros chloroxylon purchased from a local herb vendor in Ogbomoso, Nigeria, were authenticated at the Department of Biology, Botany Unit, Ladoke Akintola University of Technology, Ogbomoso, and a voucher specimen was deposited in the herbarium. The 
collected leaves were rinsed with distilled water, air dried and powered using an electrical blender. The powered leaf was soaked in methanol and allowed to stand for 72 hours. This process of extraction was repeated twice and the extract was collected, filtered and concentrated under vacuum using rotary evaporator at $45^{\circ} \mathrm{C}$.

The crude extract obtained was used for the study.

\subsection{Experimental Animals and Study Design}

Twenty-four male Wistar rats (Average weight of $137.30 \mathrm{~g}$ ) were purchased from the Animal House of the Institute of Advanced Medical Research and Training (IAMRAT), University College Hospital (UCH), Ibadan, Nigeria. Animals were treated based on my institution ethics and conduct for handling experimental animals which conforms with the international standards. The rats were assigned into four groups (six rats per group) and housed in plastic cages and fed on rats pellets and drinking water was given ad libitum. The rats were acclimatized for 7 days before the experiment and subjected to 12-h light/dark cycle and temperature of $29 \pm 2$ ${ }^{0} \mathrm{C}$. Control group received distilled water. DCLE group received daily oral intubation of DCLE $(100 \mathrm{mg} / \mathrm{kg}$ ) alone for 14 days. DMA group received intraperitoneal injection of DMA (5 $\mathrm{mg} / \mathrm{kg}$ ) twice per week, while [DCLE + DMA] group received daily oral intubation of DCLE $(100 \mathrm{mg} / \mathrm{kg})$ for 14 days and intraperitoneal injection of DMA $(5 \mathrm{mg} / \mathrm{kg})$ twice per week.

\subsection{Collection of Blood and Liver}

On day 14, the rats were fasted overnight and then sacrificed by cervical decapitation on day 15. Blood was collected by ocular bleeding after decapitation, allowed to coagulate, and centrifuged at $3000 \times \mathrm{g}$ for 10 minutes to obtain the serum used for biochemical analysis. Liver was excised, washed in $1.15 \% \mathrm{KCl}$ solution (washing buffer) to remove bloodstains, dried and then weighed. One portion of the tissue was homogenized in $0.01 \mathrm{M}$ Phosphate buffer ( $\mathrm{pH}$ 7.4) using Teflon homogenizer and then centrifuged at $10,000 \times \mathrm{g}$ to obtain homogenate used for antioxidant assays. The second portion of the liver was processed for DNA fragmentation assay. The third portion of the tissue was preserved in $10 \%$ formalin for histopathology and immunohistochemical staining.

\subsection{Biochemical Assays}

\subsubsection{Protein determination}

Total protein concentrations of serum and liver were determined as described by Lowry et al. [31].

\subsubsection{Superoxide dismutase (SOD) activity determination}

Superoxide dismutase activity in liver homogenate was determined by the epinephrine method as previously described by Mistra and Fridovich [32].

\subsubsection{Catalase (CAT) activity determination}

Catalase activity in liver homogenate was spectrophotometrically assayed according to Aebi [33].

\subsubsection{Reduced Glutathione (GSH) determination}

Reduced Glutathione level in liver homogenate was assayed according to the method described by Mitchell et al. [34].

\subsubsection{Malondialdehyde (MDA) level determination}

Lipid peroxidation in liver homogenate was estimated by determining the concentration of malondialdehyde (MDA) as described by Ohkawa et al. [35]. The MDA concentration was calculated using a molar extinction coefficient $(\mathcal{E})$ of $1.56 \times 10^{5} \mathrm{M}^{-1} \mathrm{~cm}^{-1}$.

\subsubsection{DNA Fragmentation by diphenylamine (DPA) assay}

The Diphenylamine (DPA) method described by Wu et al. [36] (with some modifications) was used to determine hepatic fragmented DNA. The liver was homogenized in Tris-EDTA (TE) buffer and then centrifuged using cold centrifuge at $27000 \times \mathrm{g}$ for 10 minutes to separate the nonfragmented DNA (pellet) from the fragmented DNA (supernatant). Each of the pellet and supernatant was treated with freshly prepared DPA reagent and the reaction mixture was incubated at $37^{\circ} \mathrm{C}$ for $16-24$ hours to allow colour development. The absorbance was read spectrophotometrically at $620 \mathrm{~nm}$. The percentage fragmented DNA was calculated according to the formula: 
$\%$ Fragmented $\mathrm{DNA}=$ (Absorbance of supernatant / (Absorbance of pellet+ Absorbance of supernatant) $\times \frac{100}{1}$

\subsubsection{Histopathological analysis}

Liver and kidney were fixed in $10 \%$ buffered formaldehyde and processed paraffin sectioning. The tissue sections were stained with haematoxylin and eosin (H \& E) and then examined under microscope.

\subsubsection{Immunohistochemical (IHC) staining}

Immunochemical staining of CD 34 in liver was done in paraffin-embedded tissue according to the method of Chakravarthi et al. [37], with slight modifications. The deparaffinised liver sections were subjected to the peroxidase labeled streptavidin-biotin technique, using the monoclonal antibody against CD34 antigen. Peroxidase blocking was carried out on the sections by covering the sections with $3 \%$ hydrogen peroxide for 15 minutes. The sections were washed with phosphate buffered saline (PBS) and protein blocking was done using avidin for 15 minutes. The sections were washed with PBS and endogenous biotin in the liver was blocked for 15 minutes, followed by incubation with $5 \mu \mathrm{g} / \mathrm{ml}$ each of anti-Bcl-2, anti-Ki-67 and anti-CD15 antibodies (diluted in 1:100) for 60 minutes. PBS was used to wash excess antibodies followed by application of secondary antibodies (LINK) on the sections for 15 minutes. The sections were washed and Horseradish peroxidase (HRP) label was applied on the sections for 15 minutes, and then washed with PBS for 5 minutes to remove unbound HRP. Visualization of the reaction products was done by immersing the section in Karnovsky solution (0.01\% diaminobenzidine (DAB) in Tris buffer containing $0.05 \%$ hydrogen peroxide and $0.01 \%$ sodium azide). Excess DAB solution and precipitate were washed off with distilled water. The tissue sections were counterstained with Haematoxylin solution for 2 minutes. The slides were dehydrated in alcohol, cleaned in xylene, mounted in DPX mountant and then observed under microscope. Cells with specific brown colour in the cytoplasm, cell membrane or nuclei, depending on the antigenic sites, were considered positive.

\subsection{Statistical Analysis}

All values were expressed as the mean \pm standard deviation of six animals per group. Data were analyzed using one-way analysis of variance (ANOVA) followed by the post-hoc Duncan multiple test for analysis of biochemical data using SPSS (10.0). Statistically significant values were taken at $p<0.05$.

\section{RESULTS AND DISCUSSION}

\subsection{Results}

The data in Table 1 show that the body weight gain in rats treated with DMA was $35.13 \pm 2.80 \mathrm{~g}$, compared with that of the control rats which was $21.50 \pm 1.22 \mathrm{~g}$. However, on treatment with DCLE against DMA, the weight gain was found to be $24.75 \pm 1.86 \mathrm{~g}$, showing a significant $(P=.05)$ reduction in weight gain in the rats. We observed that liver weight was significantly $(P$ $=.05$ ) elevated by DMA treatment up to $21 \%$ compared with controls, while a significant reduction of up to $32.3 \%$ was noticed in the [DCLE + DMA] group of the rats, compared with DMA-intoxicated rats. Furthermore, DMA treatment significantly $(P=.05)$ elevated the relative weight of liver by $20 \%$ relative to control rats, whereas, the DCLE pretreatment reduced the relative weight in a slightly significant manner, compared with DMA-intoxicated group.

The antioxidant effect of DCLE against DMA intoxication in the experimental rats, was investigated by examining parameters including Superoxide dismutase (SOD), catalase, reduced glutathione (GSH) and malondialdehyde (MDA) in both the serum and liver of the rats. Table 2 shows that DMA significantly $(P=.05)$ lowered the activities of serum SOD and catalase by $43.9 \%$ and $60.6 \%$, respectively compared with controls. Although there were no significant changes in the level of GSH, the level of MDA was found to be significantly $(P=.05)$ elevated by $150 \%$ relative to controls. On pretreatment with DCLE, the activities of serum SOD and catalase were observed to significantly $(P=.05)$ increase by $50.6 \%$ and $110.7 \%$, respectively, while MDA level was significantly $(P=.05)$ reduced against DMA intoxication. Table 3 shows that DMA treatment significantly $(P=.05)$ reduced the activities of hepatic SOD and catalase, and GSH level by $49.9 \%, 32 \%$ and $26.3 \%$, respectively compared with control rats. The level of MDA was, however, noticed to be significantly $(p<$ 0.05 ) elevated by $94.5 \%$ relative to controls. In contrast, when the rats were pretreated with DCLE and then co-treated with DMA, the activities of SOD and catalase were significantly $(p<0.05)$ increased by $59 \%$ and $89.7 \%$, while the level of GSH was increased, and that of MDA 
was reduced by $51.5 \%$ and $78.9 \%$, respectively compared with DMA-treated rats.

As shown in Fig. 1, DMA significantly $(P=.05)$ increased hepatic DNA fragmentation by $42.5 \%$, compared with the control rats, while pretreatment with DCLE significantly $(P=.05)$ reduced the level of fragmented DNA by $35.7 \%$ relative to DMA-treated rats.

The histological data show that DMA intoxication caused hepatocyte periportal cell infiltration

Table 1. Effects of DCLE on body weight and relative weights of liver of rats treated with DMA

\begin{tabular}{|c|c|c|c|c|c|}
\hline \multirow[t]{2}{*}{ Treatments } & \multicolumn{3}{|c|}{ Weights of rats $(\mathrm{g})$} & \multirow{2}{*}{$\begin{array}{l}\text { Weight of } \\
\text { liver (g) }\end{array}$} & \multirow{2}{*}{$\begin{array}{l}\text { Liver relative } \\
\text { weight (\%) }\end{array}$} \\
\hline & Initial & Final & Weight gain & & \\
\hline & 13 & 0 & & $2.74 \pm 0.55$ & $1.61 \pm 0.10$ \\
\hline & 15 & & & & \\
\hline DMA & $136.50 \pm 16.24$ & $171.63 \pm 12.62$ & $35.13 \pm 2.80^{\mathrm{b}}$ & $3.32 \pm 0.28^{b}$ & $1.93 \pm 0.50^{\mathrm{b}}$ \\
\hline DCLE + DMA & $128.70 \pm 14.70$ & $153.45 \pm 14.44$ & $24.75 \pm 1.86^{\mathrm{c}}$ & $2.51 \pm 0.12^{\mathrm{c}}$ & $1.64 \pm 0.24^{c}$ \\
\hline
\end{tabular}

DCLE: Diospyros chloroxylon leaf extract; DMA: Dimethylamine

${ }^{a}$ Data expressed in mean $\pm S D, n=6,{ }^{b}$ statistically different $(P=.05)$ compared with control, ${ }^{c}$ statistically different $(P=.05)$ compared with DMA-group

Table 2. Effects of DCLE on antioxidant indices in serum of rats treated with DMA

\begin{tabular}{|c|c|c|c|c|}
\hline Treatments & $\begin{array}{l}\text { SOD (U/mg } \\
\text { protein) }\end{array}$ & $\begin{array}{l}\text { CAT (U/mg } \\
\text { protein) }\end{array}$ & $\begin{array}{l}\mathrm{GSH}(\mu \mathrm{g} / \mathrm{mg} \\
\text { protein) }\end{array}$ & MDA ( $\mu \mathrm{M} / \mathrm{mg}$ protein) \\
\hline Control & $4.51 \pm 0.18$ & $7.11 \pm 1.07$ & $2.57 \pm 0.01$ & $1.94 \pm 0.81$ \\
\hline DCLE & $3.33 \pm 0.10$ & $6.38 \pm 0.78$ & $3.05 \pm 0 . .65$ & $2.26 \pm 0.24$ \\
\hline DMA & $2.53 \pm 0.12^{\mathrm{b}}$ & $2.80 \pm 0.77^{\mathrm{b}}$ & $2.35 \pm 0.98$ & $4.85 \pm 1.03^{\mathrm{b}}$ \\
\hline $\mathrm{DCLE}+\mathrm{DMA}$ & $3.81 \pm 0.21^{\mathrm{c}}$ & $5.90 \pm 1.11^{\mathrm{c}}$ & $2.74 \pm 1.71$ & $3.10 \pm 1.17^{c}$ \\
\hline \multicolumn{5}{|c|}{ 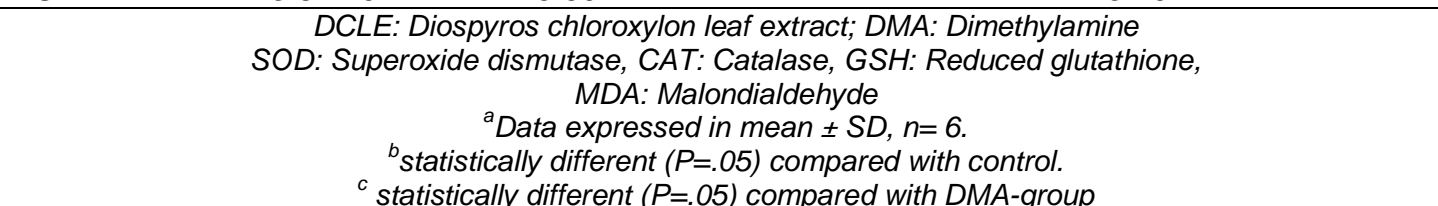 } \\
\hline
\end{tabular}

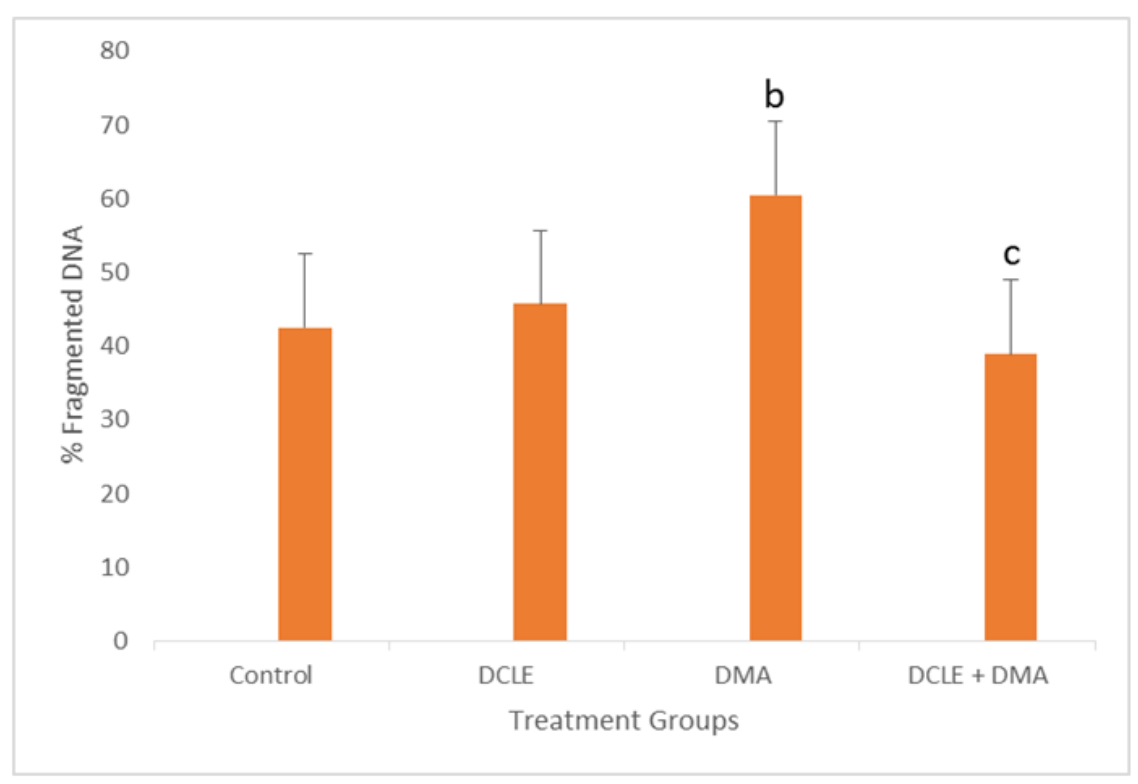

Fig. 1. Effect of DCLE on hepatic DNA fragmentation in rats treated with DMA DCLE: Diospyros chloroxylon leaf extract; DMA: Dimethylamine ${ }^{b} P=.05$ : statistically different compared with control, ${ }^{c} P=.05$ : statistically different 
compared with DMA group

(Fig. 2C), while visible lesions were not detected in both DCLE (Fig. 2B) and DCLE + DMA groups (Fig. 2D) comparable to controls (Fig.2A). The data in Fig. 3 show the immunohistochemical study of the liver of the experimental rats. In Fig. 3C, DMA intoxication was observed to cause a strong expression of CD34 marker. However,
DCLE treatment alone resulted in mild expression of CD34 (Fig. 3B) comparable to controls (Fig. 3A), while a treatment of the experimental animals with a combination of DCLE and DMA was observed to cause moderate expression of CD34 protein (Fig. 3D).

Table 3. Effects of DCLE on antioxidant indices in liver of rats treated with DMA

\begin{tabular}{lllll}
\hline Treatments & $\begin{array}{l}\text { SOD }(U / \mathbf{m g} \\
\text { protein) }\end{array}$ & CAT $(U / m g$ protein) & $\begin{array}{l}\text { GSH }(\mu \mathrm{g} / \mathbf{m g} \\
\text { protein) }\end{array}$ & $\begin{array}{l}\text { MDA }(\mu \mathrm{M} / \mathbf{m g} \\
\text { protein })\end{array}$ \\
\hline Control & $7.50 \pm 0.45$ & $6.25 \pm 1.33$ & $13.75 \pm 2.11$ & $1.83 \pm 0.14$ \\
DCLE & $9.23 \pm 1.12$ & $5.45 \pm 0.22$ & $11.67 \pm 0 . .98$ & $2.15 \pm 0.76$ \\
DMA & $3.76 \pm 0.19^{\mathrm{b}}$ & $4.25 \pm 1.00^{\mathrm{b}}$ & $10.13 \pm 1.21^{\mathrm{b}}$ & $3.56 \pm 1.07^{\mathrm{b}}$ \\
DCLE + DMA & $5.98 \pm 0.23^{\mathrm{c}}$ & $8.06 \pm 2.65^{\mathrm{c}}$ & $15.35 \pm 1.88^{\mathrm{c}}$ & $1.99 \pm 0.77^{\mathrm{C}}$ \\
\hline
\end{tabular}
SOD: Superoxide dismutase, CAT: Catalase, GSH: Reduced glutathione, MDA: Malondialdehyde

${ }^{a}$ Data expressed in mean $\pm S D, n=6,{ }^{b}$ statistically different $(P=.05)$ compared with control ${ }^{c}$ statistically different $(P=.05)$ compared with DMA-group
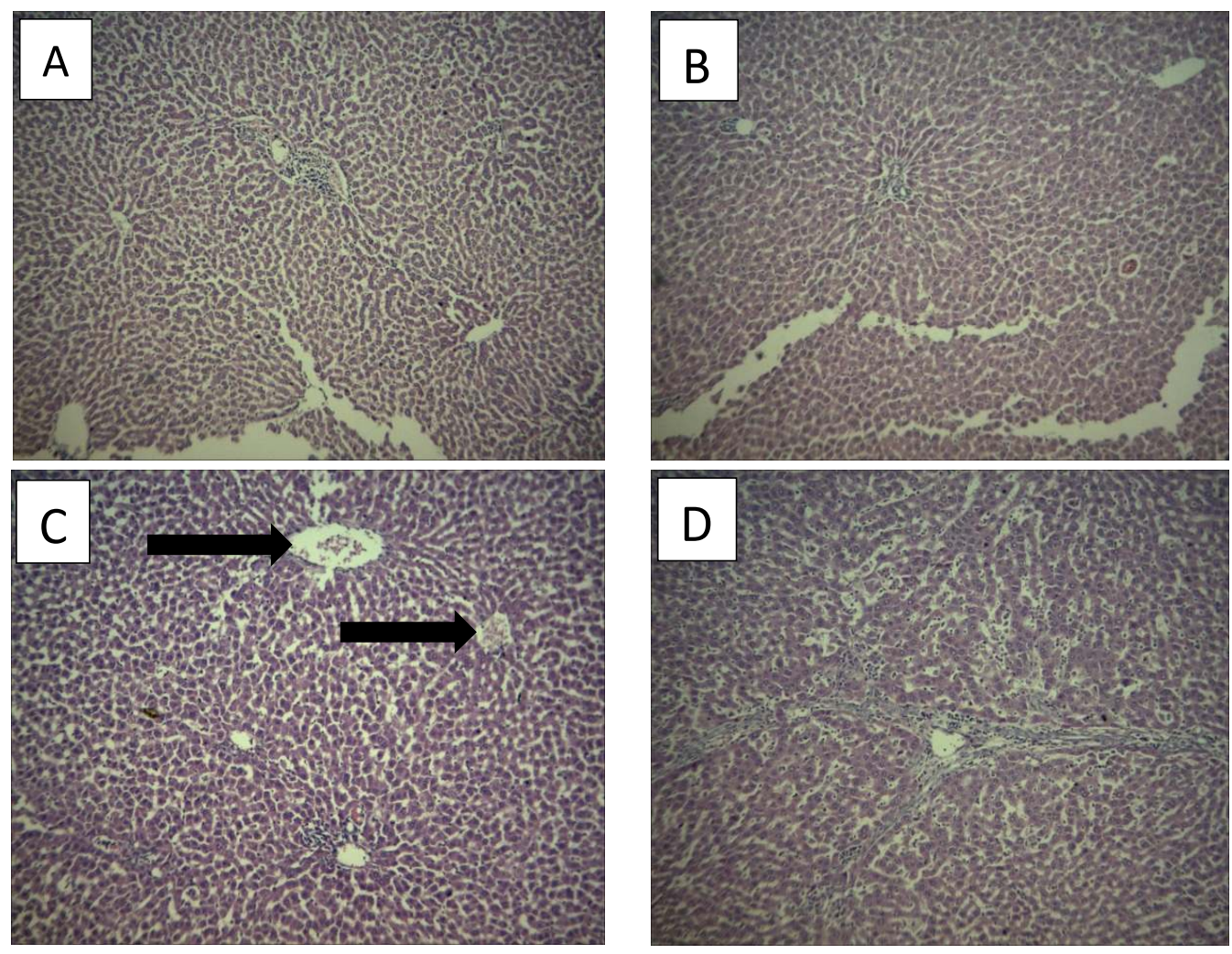

Fig. 2. Histopathological sections of liver (stained with H\&E) (A) Liver section from control rats showing no visible lesion (x 100), (B) Liver section from DCLE group showing no visible lesion (x 100), (C) Liver section from DMA group showing hepatocyte periportal cell infiltration (x 100) (areas of lesion indicated with black arrows) and (D) Liver section from [DCLE + DMA] group showing no visible lesion (x 100) 

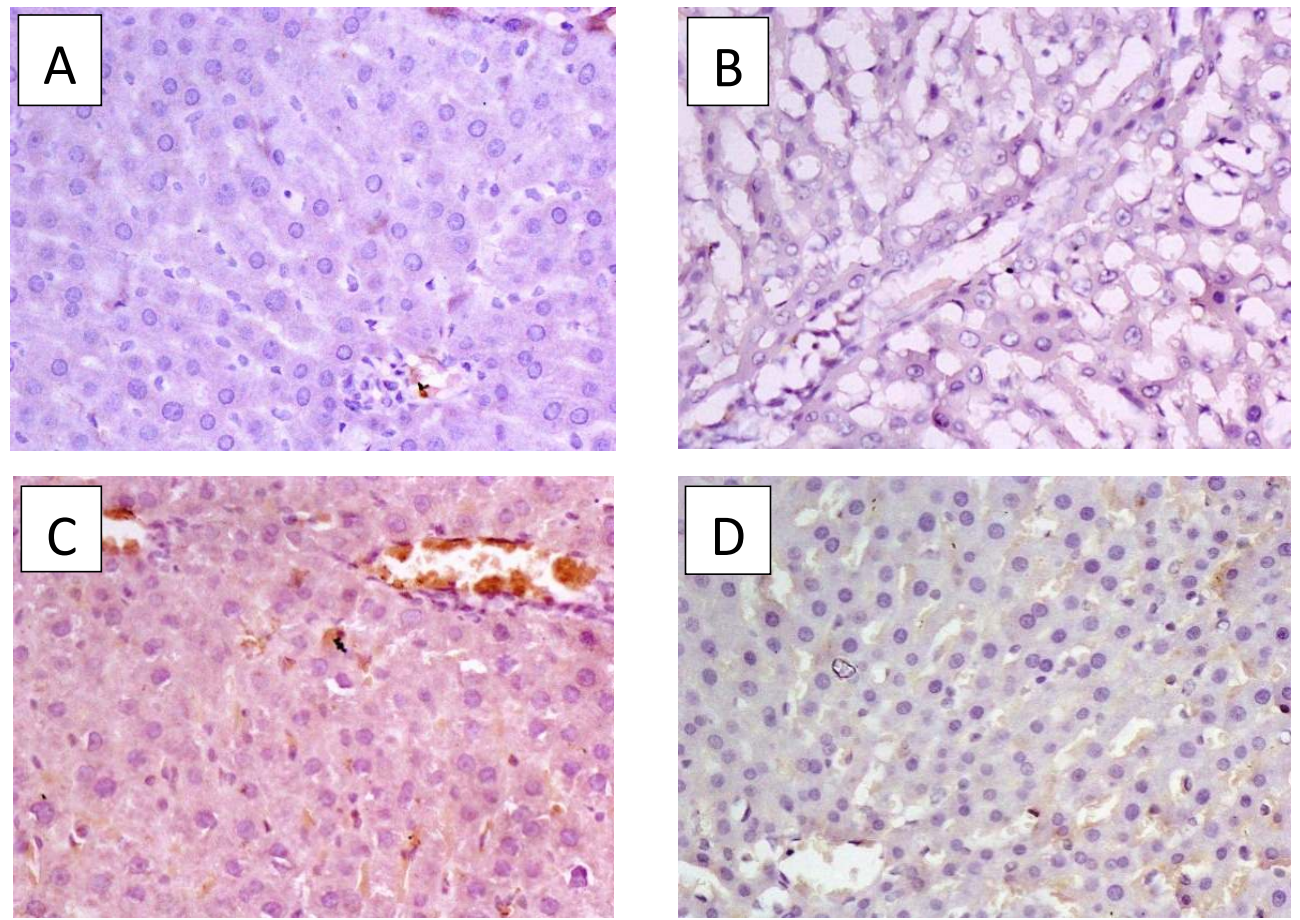

Fig. 3. Immunohistochemical (IHC) staining of liver sections. (A) Liver section from control rats showing mild expression of CD34, (B) Liver section from DCLE group showing mild expression of CD34, (C) Liver section from DMA group showing strong expression of CD34 and (D) Liver section from [DCLE + DMA] group showing moderate expression of CD34

\subsection{Discussion}

In the present study, we investigated the effect of dimethylamine (DMA) and D. chloroxylon leaf extract (DCLE) on liver of rats. Our finding shows that DMA caused a significant increase in body weight gain in rats relative to control. A previous study using $\mathrm{N}$-nitrosodimethylamine (NDMA), which is the nitrosated form of dimethylamine, revealed that this nitrosamine caused a significant increase in body weight gain in experimental rats [38]. This may therefore indicate a tendency of overweight and obesity, processes that are closely linked to cardiovascular diseases (CVDs). When the rats were treated with DCLE in combination with DMA, the weight gain was significantly lowered, compared with DMA group, suggesting the potential of the phytochemicals present in the extract for weight regulation. The weight and relative weight of liver of the rats were noticed to be elevated in the DMA group, whereas DCLE supplementation was found to ameliorate the effects.

Oxidative stress is a redox status induced when the level of reactive oxygen species (ROS) outweighs the defensive activity of cellular antioxidant system in the body. As a result, cellular macromolecules, such as DNA, proteins and lipids become oxidized, resulting in lipid peroxidation, DNA damage and modulation of antioxidant system [39-40], gene alteration [41], cell proliferation [42], chromosomal damage, genetic mutation and tumorigenesis [43]. Superoxide dismutase (SOD) converts superoxide anion to hydrogen peroxide [44], which is finally decomposed into water and oxygen [45-46]. In this study, we observed that DMA significantly reduced serum and hepatic SOD and catalase activities, while MDA levels were elevated compared with controls. In the hepatic tissue, GSH was significantly reduced in DMA group, while the serum level was not significantly changed relative to control rats. The reductions being noticed in SOD, catalase and GSH, with a concomitant increase in MDA in the DMA-treated rats suggest generation of reactive oxygen species (ROS) and oxidative stress in this group of rats. Several studies have shown that nitrosated amines, including dimethylamine $[38,47]$, diethylamine (DEA) [48] and $N$-butyl- $N$ (4-hydroxybutyl) amine (BBA) [49] significantly 
increased MDA level, and reduced SOD, catalase and GSH. The observed reduction in SOD and catalase activities may be an indication of the inhibitory effect of DMA on these antioxidant enzymes, consistent with a similar result using NDMA [50]. When the rats were pretreated with methanolic $D$. Chloroxylon leaf extract (DCLE) prior to DMA treatment, serum and hepatic SOD and catalase activities were significantly elevated, while MDA levels were reduced. The pretreatment with DCLE caused a significant elevation in hepatic GSH, while the serum level was not significantly changed relative to DMA treatment. A related study using NDMA showed that DCLE improved the antioxidant system in rats treated with this compound [38]. The observed ameliorative effect of the extract, suggests that the constituents of $D$. Chloroxylon leaf could exert beneficial redox profile and boost antioxidant enzymes activities in DMA-treated rats.

DNA fragmentation analysis, using diphenylamine (DPA) method [36], showed that DMA caused a significant increase in percentage fragmented DNA in the hepatic tissue relative to control rats. The presence of nucleosomal DNA degradation or DNA fragments in a normal cell is a marker of physiologic apoptosis [51-53]. An investigation by Perandones et al. [54] revealed that endonuclease activation occurring during apoptosis may be a cause of nucleosomal DNA fragmentation and induction of DNA strand breaks [55]. The fact that DMA-treated rats showed significantly higher level of fragmented DNA than control rats may be an indication of pathologic apoptosis taking place in the toxicanttreated animals. Pathologic apoptosis occurs when there is malfunctioning of the cell cycle regulatory mechanisms leading to either inadequate apoptosis or excessive apoptosis, associated with carcinogenesis and autoimmune diseases [56-57]. Some of our studies [20,38] and others [50] have established that NDMA could cause significantly high DNA fragmentation, hence pathologic apoptosis and DNA damage. When the rats were co-treated with DCLE and DMA, the level of DNA fragmentation in the organ was significantly reduced relative to DMA treatment alone. We recently reported the potential of DCLE in reducing the level of DNA fragmentation induced in rats administered with NDMA [38]. This result indicates that the extract prevents DNA damage, and may also prevent pathologic apoptosis.
Histological evaluation showed no visible lesions in the DCLE and DCLE + DMA groups comparable to control rats. However, the rats treated with DMA showed infiltrative lesion of the hepatocytes. Studies carried out by Farombi et al. [47], Lee et al. [58] and Lin et al. [59], revealed that NDMA induced fibroplasia (fibrosis) in hepatocytes of rats administered with this nitrosamine. In addition, a co-treatment of DMA and nitrite was noticed to cause hepatic necrosis in Wistar rats [19]. Supporting the conventional histopathological examination, we also carried out immunohistochemical (IHC) staining of CD34 of the hepatic tissue, to detect tumor presence, and whether the tumoral lesion has a tendency towards benign or malignancy. CD34 is a transmembrane glycoprotein expressed on cells of the haematopoietic stem, endothelium and mesenchyma, and vascular-related tissues [6062]. Although the actual function of CD34 has not been clearly elucidated [63], this glycoprotein is thought to be responsible for modulation of cellto-cell adhesion, signal transduction and entry of T-cells into lymph nodes. CD34 binds to Lselectin on T-cells, and when these cells enter the lymph nodes, the protein becomes expressed on the surface of lymph node endothelia [64-65]. Immunohistochemical staining revealed a strong expression of CD34 in the hepatic tissue of rats treated with DMA. CD34 has been used as a key tumor marker in cervical [66] and prostate cancers [67]. In addition, it has been established that stem cells derived from cancerous tissues show persistent surface expression of CD34 antigen, with increased proliferative capacity and lack of differentiation [68], although we did not investigate stem cells from the hepatic tissue in this study. Furthermore, investigations have shown that CD34 expression may be a useful diagnostic tool in distinguishing between malignant and benign lesions [69-70]. The benign tumours have been associated with CD34 expression, while its non-expression may be a possible indication of malignancy, as depicted with invasive carcinomas, showing no CD34 expression [71-73]. Our finding on CD34 thus demonstrates that dimethylamine could induce cell proliferation, showing a tendency of being benign. In contrast, the rats treated with DCLE alone showed mild expression of CD34, comparable to control rats, while the treatment with a combination of DCLE and DMA showed moderate expression of CD34. This finding here suggests a preventive action of the extract (DCLE) used in this study against possible DMA- 
induced cell proliferation and tumorigenesis. This suggestion is however open to further research.

\section{CONCLUSION}

In conclusion, our findings from the present study show that dimethylamine could induce oxidative stress, DNA damage and cell proliferation, which are indispensable in tumorigenesis, in liver of the experimental rats. The methanolic leaf extract of $D$. Chloroxylon was able to ameliorate the effects, showing the potential of this extract to protect against dimethylamine-induced toxicity in rats.

\section{CONSENT}

It is not applicable.

\section{ETHICAL APPROVAL}

It is not applicable.

\section{COMPETING INTERESTS}

Authors have declared that no competing interests exist.

\section{REFERENCES}

1. Turkesky RJ, Rossi SC, Welti DH, Lay JO Jnr., Kadlubar FF. Characterization of DNA-adducts formed in vivo by reaction $N$ hydroxyl-2- amino- 3 - methylimidazo $(4,5,-$ f) quinoline and $N-$ hydroxyl $-2-$ amino - 3,8 - dimethylimidazo $(4,5-f)$ quinoxaline at the $\mathrm{C} 8$ and $N^{2}$ atoms of guanine. Chem. Res. Toxicol. 1992;5:479490.

2. Herman AJ, Synderwine EG. (1999). DNA adducts of heterocyclic amine food mutagens: Implications for mutagenesis and carcinogenesis. Carcinogenesis. 1999;20(3): 353 - 368.

3. Otsuka C, Miura KF, Satoh T, Hatanaka M, Wakabayashi K, Ishidate M. Jnr. Cytogenetic effects of a food mutagen, 2 amino - 1 - methyl - 6 - phenylimidazo $(4,5-b)$ pyridine (PhIP) and its metabolite, 2- hydroxyamino 1 - methyl - 6 phenylimidazo $(4,5-\mathrm{b})$ pyridine $(\mathrm{N}-\mathrm{OH}-$ PhIP) on human and Chinese hamster cells in vitro. Mutat Res. 1996;367:115121.
4. Sugimura T. Overview of carcinogenic heterocyclic amines. Mutat. Res. 1997; 376:211-219.

5. Sacher F, Schmidt CK, Lee C, Gunten UV. Strategies for minimizing nitrosamine formation during disinfection. Awwa Research Foundation, Denver, CO. (Report No. 91209); 2008.

6. Herrmann SS, Deudahl-Olesen L, Granby $\mathrm{K}$. Occurrence of volatile and non-volatile $\mathrm{N}$-nitrosamines in processed meat products and role of heat treatment. Food Control. 2015;48:163-169.

7. Herrmann SS, Granby K, Deudahl-Olesen L. Formation and mitigation of $\mathrm{N}$ nitrosamines in nitrite-preserved cooked sausages. Food Chem. 2014;174:516-526.

8. Iqbal ZM, Epstein SS, Krull IS, Goff U, Mills K, Fine DH. Kinetics of nitrosamine formation in mice following oral administration of trace level precursors. IARC Sci. Publ. 1981;31:169.

9. Iqbal ZM. DNA binding in organs of mice exposed to Dimethylamine by gavage and nitrogen dioxide by inhalation. Proc. Am. Assoc. Cancer Res. 1986;27:85.

10. Adeleke GE, Akpabio CJ, Oyewo EB, Maduagwu EN. Acetobacter aceti isolated from fermented palm wine in the SouthWest region of Nigeria elucidated high Nitrosamine production in the presence of nitrite. The Journal of Toxicology and Health. Photon. 2015;106:494-502.

11. Ayanaba A and Alexander M. Microbial formation of nitrosamines in vitro. Applied Microbiology. 1973;25(6):862-863.

12. Kunisaki N, Hayashi M. Formation of secondary amines and nitrite by resting cells of Escherichia coli B. Appl. and Environ. Microbiol. 1979;37(1):279- 282.

13. World Health Organization. N-nitrozamine. Concise international chemical assessment document 38 (CICADS 38) World Health Organization. Geneva, Switzerland; 2002.

14. National Toxicology Program. Nnitrosdimethylamine; CAS no. 62-75-9. Eleventh report on Carcinogens. Public Health Service, U.S. Department of Health and Human services. Washington, DC; 2004.

15. United State Environmental Protection Agency. USEPA, an integrated risk information system for $\mathrm{N}$ nitrosodimethylamine (CASRN 62-75-9); 2006. 
16. Kumaraguruparan $\mathrm{R}$, Chandra-Mohan KV, Abraham SK, Nagini S. Attenuation of $\mathrm{N}$ meethyl- $\mathrm{N}^{1}$-nitro- $\mathrm{N}$-nitrosoguanidineinduced genotoxicity and oxidative stress by tomato and garlic combination. Life Sci. 2005;76:2247-2255.

17. Arranz N, Haza Al, Garcia A, Rafter J, Morales P. Protective effect of vitamin C towards $\mathrm{N}$-nitrosamine-induced DNA damage in the single-cell gel electrophoresis (SCGE)/HepG2 assay. Toxicol. In vitro. 2007;21:1311-1317.

18. Ghosh D, Choudhury ST, Das N. Nanocapsulated curcumin: Oral chemopreventive formulation against DENinduced hepatocellular carcinoma in rat. Chemico-Biological Interaction. 2012; 195(3):206-214.

19. Usunomena U, Sunday JJ, Specer N, Esosa US, Kingsley O, Maduagwu NE. Toxicity evaluation of the liver and in vitro metabolism in Wistar rats on exposure to $\mathrm{N}$-nitrosamine precursors. $\mathrm{Br}$. J. Pharmacol. 2011;2(3):138-142.

20. Adeleke GE, Adaramoye OA. Modulatory role of Betulinic acid in $N$ nitrosodimethylamine-induced hepatorenal toxicity in male rats. Hum and Expert Toxicol. 2016;1-10.

21. Reddy KN, Trimurthulu G, Reddy SC. Medicinal plants used by ethnic people of Medak district, Andhra Pradesh. Indian Journal of Traditional Knowledge. 2008; 9(1): 184-190.

22. Mallavadhani UV, Panda AK, Rao YR. Pharmacology and chemotaxonomy of Diospyros. Regional research laboratory (CSIR), Orissa, India. Phytochemistry. 1998;49(4):901-951.

23. Santosh MK, Shaila D, Sharanabasappa GK, Seetharam YN, Sanjeevarao I. Phytochemical studies on Bauhinia racemosa Lam. Bauhinia purpuria Linn and Hardwickia binate Rob. E. J. Chem. 2007; 4(1):21-31.

24. Kim DSHL, Chen Z, Nguyen VT, Pezzuto JM, Qui S, Lu ZZ. A concise semi-synthetic approach to betulinic acid from betulin. Synth. Commun. 1997;27:1607-1612.

25. Thomas RP, Antony AM, Mamen AA. Comparative phytochemical analysis of Diospyros chloroxylon leaves in various extracts. Int. J. Sci. Res. Pub. 2013;3(9): 2250-3153.

26. Singh $P$, Sharma S. Triterpenoid constituents of the seed of Diospyros melanozylon, Tecomella undulata and
Terminalia bellirica. J. Indian Chem Soc. 1997;74:504-505.

27. Higa M, Ogihara K, Yogis N. Bioactive naphthoquinone derivatives from dispyros maritime blume. Chem. Pharm Bull. 1998; 46:1189-1193

28. Fulda S. Betulinic acid for cancer treatment and prevention. Int. J. Mol. Sci. 2008;9: 1096-1107.

29. Chadalapaka G, Jutooru I, Burghardt R, Safe S. Drugs that target specificity proteins down regulate epidermal growth factor receptor in bladder cancer cells. Mol. Cancer Res. 2010;8:739-750.

30. Chintharlalli S, Papineni S, Lei P, Pathi S, Safe S. Betulinic acid Inhibits colon cancer cell and tumor growth and induces proteasome: Dependent and independent down regulation of specificity proteins (sp) transcription factors. BMC Cancer. 2011; 11:371-382.

31. Lowry $\mathrm{OH}$, Rosebrough $\mathrm{NJ}$, Farr $\mathrm{AL}$, Randall R J. Protein measurement with the Folin phenol reagent. J. Boil. Chem. 1951; 193:265-275.

32. Misra HP, Fridovch J. The role of superoxide anion in the autoxidation of epinephrine and a simple assay for superoxide dismutase. J. Biol. Chem. 1975;247:3170-3175.

33. Aebi H. Catalase in vitro. In: Packer L. Editor. Methods in enzymology. Orlando FL: Academic Press. 1984;121-126.

34. Mitchell JR, Jollow DJ, Potter WZ, Davis DC, Gillette JR, Brodi BB. Acetaminopheninduced hepatic necrosis. I. Role of drug metabolism. J. Pharmacol Exer Therap. 1973;187:185-194.

35. Ohkawa H, Ohishi N, Yagi K. Assay for lipid peroxides in animal tissues by Thiobarbituric acid reaction. Anal Biochem. 1979;95:351-358.

36. Wu B, Ootani A, Iwakiri R, Sakata Y, Fujise $\mathrm{T}$, Amemori $\mathrm{S}$, et al. T cell deficiency leads to liver carcinogenesis in azoxymethanetreated rats. Exp Biol Med. 2005;231:9198.

37. Chakravarthi S, Long AS, Hannien B, Pasupati T, Palayan K, Talib A. The expression of p53 as a reliable immunohistochemical marker of gastric adenocarcinomas. Res. J. Med. Sci. 2010; 4(1):15-19.

38. Adeleke GE, Adedosu OT, Adaramoye OA, Olagunju AS, Teibo OJ, Arinde OO, et al. Hepatoprotective effect of methanol extract of Diospyros chloroxylon leaf in 
$\mathrm{N}$-nitrosodimethylamine-induced hepatotoxicity in rats. Asian Pacific J Health Sci. 2016;3(3):142-152.

39. Kamendulis LM, Jiang J, Xu D, Klaunig JE. Induction of oxidative stress and oxidative damage in rat glial cells by acrylonitrile. Carcinogenesis. 1999;20:1555-1560.

40. $\mathrm{Pu} \mathrm{X}$, Kamendulis LM, Klaunig JE. Acrylonitrile-induced oxidative DNA damage in rat astrocytes. Environ $\mathrm{Mol}$ Mutagen. 2006;47:631-638.

41. Allen RG and Tresini M. Oxidative stress and gene regulation. Free Radic. Biol. Med. 2000;28:463-499.

42. Toyokuni S. Novel aspects of oxidative stress-associated carcinogenesis. Antioxid. Redox. Signal. 2006;8:1373-1377.

43. Ishikawa $\mathrm{K}$, Takenaga $\mathrm{K}$, Akimoto $\mathrm{M}$, Koshikawa N, Yamaguchi A, Imanishi $\mathrm{H}$, et al. ROS-generating mitochondrial DNA mutations can regulate tumor cell metastasis. Science. 2008;320:661-664.

44. Gajula D, Verghese M, Boateng J, Shackelford L, Mentreddy SR et al. Basil (Ocimum basilicum and Ocimum tenuiflorum) reduces azoxymethaneinduced colon tumors in Fischer-344 male rats. Res. J. Phytochem. 2010;4:136145.

45. Fridovich J. Superoxide dismutases. Ann. Rev. Biochem. 1975;44:147-159.

46. Bansal AK, Bhaknagar D, Soni GL. In vitro effect of $\mathrm{N}$-nitrosodimethylamine on lipid peroxidation and antioxidant system in human erythrocytes. Toxicol. In vitro. 1996; 10:649-653.

47. Farombi EO, Shrotriya S, Surh Y. Kolaviron inhibits dimethylnitrosamineinduced liver injury by suppressing COX-2 and iNOS expression via NF-kB and AP-1. Life Sci. 2009;84:149-155.

48. Hussain $T$, Siddiqui HH, Sheeba $F$, Vijayakumar M, Rao CV. Evaluation of chemopreventive effect of Fumaria indica against NDEA- and $\mathrm{CCl}_{4}$-induced hepatocellular carcinoma in wistar rats. Asian Pacific Journal of Tropical Medicine. 2012;5(8): 623-629.

49. Oliveira MM, Teixeira JC, VasconcelosNobrega C, Felix LM, Sardao VA, Colaco $A A$, et al. Mitochondrial and liver oxidative stress alterations induced by BBN: relevance for hepatotoxicity. J. Appl Toxicol. 2013;33(6):434-443.

50. Patterson J, Boateng J, Walker LT, Verghese M. Cytotoxic effects of multiple $\mathrm{N}$-nitrosamines in human -liver cell line
Hep 2G: Possible mechanisms of action. J. Pharmacol. Toxicol. 2012;1-14.

ISSN: 1816

DOI: 10.3923/jpt

51. Li LY, Luo X, Wang X. Endonuclease G is an apoptotic DNase when released from mitochondria. Nature. 2001;412:95-9.

52. Elmore S. Apoptosis: A review of programmed cell death. Toxicol. Pathol. 2007;35:495-516.

53. Dhanasekaran JJ, Ganapathy M. Hepatoprotective effect of Cassia auriculata L. leaf extract on carbon tetrachloride intoxicated liver damage in Wistar albino rats. Asian J. Biochem. 2011; 6:104-112.

54. Perandones CE, Illera VA, Peckham D, Stunz LL, Ashman RF. Regulation of apoptosis in vitro in mature muarine spleen T-cells. J Immunol. 1993;151:3521-3529.

55. Diab KAE, ELmakawy Al, Abd-Elmoneim OM, Sharaf HA. Assessment of genotoxicity and histopathological changes induced by polyethylene glycol (PEG600) in male mice. J. Cytol Histol. 2012;3(5):1-7.

56. Li CJ, Friedman DJ, Wang C, Metelev V, Pardee AB. Induction of apoptosis in uninfected lymphocytes by HIV-1 tat protein. Sci. 1995;268:429-31.

57. King KL and Cidlowski JA. Cell cycle regulation and apoptosis. Annu Rev Physiol. 1998;60:601-617.

58. Lee SE, Hwang HJ, Ha JS, Jeong HS, Kim $\mathrm{JH}$. Screening of medicinal plant extracts for antioxidant activity. Life Sci. 2003; 73:167e179.

59. Lin HJ, Chen JY, Lin CF, Kao ST, Cheng JC, Chen HL, et al. Hepatoprotective effects of Yi Guan Jin, an herbal medicine, in rats with dimethylamine-induced liver fibrosis. J. Ethnopharmacol. 2011;134(3): 953-60.

60. Van de Rijn M. and Rouse RV. CD34: A review. Appl Immunohistohcem. 1994;2: 71-80.

61. Kuroda N, Nakayama H, Miyazaki E. et al. Distribution and role of CD34-positive stromal cells and myofibroblasts in human normal testicular stroma. Histol Histopathol. 2004;19(3):743-751.

62. Nielsen JS and McNagny KM. Novel functions of the CD34 family. J. Cell Science. 2008;121(Pt 22):3683-92.

63. Furness SG, McNagny K. Beyond mere markers: Functions for CD34 family of sialomucins in hematopoiesis. Immunologic Res. 2006;34(1):13-32. 
64. Berg EL, Mullowney AT, Andrew DP, Goldberg JE, Butcher EC. Complexity and differential expression of carbohydrate epitopes associated with L-selectin recognition of high endothelial venules. Am J. Pathol. 1998;152(2):46977.

65. Suzawa K, Kobayashi M, Sakai Y, Hoshino $\mathrm{H}$, Watanabe $\mathrm{M}$, Harada $\mathrm{O}$, et al. Preferential induction of peripheral lymph node addressin on high endothelial venulelike vessels in the active phase of ulcerative colitis. Am. J. Gastroenterology. 2007;102(7):1499-509.

66. Viera SC, Silva BB, Pinto GA, VassalloJ, Morales NG, Santana JOI. CD34 used as a marker for evaluating angiogenesis in cervical cancer. Pathol. Res and Prac. 2005;201(4):313-318.

67. Nassif AE, Filho RT. Immunohistochemistry expression of tumor markers CD 34 and p27 as prognostic factors of clinically localized prostate adenocarcinoma after radical prostatectomy. Rev. Col. Bras. Cir. 2010; 37(5):338-344.

68. Zavan B, De Francesco F, D'Andrea F, Ferroni, Gardin C, Salzillo R, et al. Persistence of CD34 stem marker in human lipoma: Searching for cancer stem cells. Int. J Biol. Sci. 2015;11(10):11271139.

69. Swanson PE, Fitzpatrick MM, Ritter JH, et al. Immunohistologic differential diagnosis of basal cell carcinoma, squamous cell carcinoma, and trichoepithelioma in small cutaneous biopsy specimens. J Cutan Pathol. 1998; 25:153-159.

70. Nakayama $\mathrm{H}$, Enzan $\mathrm{H}$, Miyazaki $\mathrm{E}$, et al. CD34 positive stromal cells in gastric adenocarcinomas. J Clin. Pathol. 2001;54: 846-848.

71. Chauhan $\mathrm{H}$, Abraham A, Philips JRA, et al. There is more than one kind of myofibroblasts: Analysis of CD34 expression in benign, in situ, and invasive breast lesions. J Clin Pathol. 2003;56(4): 271-276.

72. Yazou C, Wenlv S, Weidong Z, Licun W. Clinicopathological significance of stromal myofibroblasts in invasive ductal carcinoma of the breast. Tum. Biol. 2004; 25(5-6):290-295.

73. Cimpean AM, Raica M, Narita D. Diagnostic significance of the immunoexpression of CD34 and smooth muscle cell actin in benign and malignant tumors of the breast. Rom. J. Morphol. Embr. 2005;46(2):123-129.

(C) 2017 Adeleke et al.; This is an Open Access article distributed under the terms of the Creative Commons Attribution License (http://creativecommons.org/licenses/by/4.0), which permits unrestricted use, distribution, and reproduction in any medium, provided the original work is properly cited.

Peer-review history:

The peer review history for this paper can be accessed here: http://sciencedomain.org/review-history/19351 